\title{
Fiscal Deficit and the Productivity of the Nigeria Tax System, 1970-2010
}

\author{
Ben U. Omojimite \\ Department of Economics, Delta State University, Abraka, Nigeria \\ Email: buomojimite@yahoo.com
}

Godwin E. Iboma

Department of Arts/Social Science, Delta State Polytechnic, Otefe-Oghara, Nigeria

Email: ibomagodmeza@gmail.com

Received: January 23, 2012

Accepted: February 25, $2012 \quad$ Published: April 1, 2012

doi:10.5539/jsd.v5n4p116

URL: http://dx.doi.org/10.5539/jsd.v5n4p116

\begin{abstract}
This study evaluates the link between fiscal deficit and the productivity of the Nigeria tax system between 1970 2010 using tax buoyancy and elasticity as indexes. It also examines some major tax reforms within the period. Overall the analysis shows that for most of the tax sources, the elasticity indexes were significantly less than 0.5 while for 3 out of the 10 equations the elasticity fell between 0.5 and 0.9 . This indicates a relatively weak productive tax system. The study also indicates that unlike the overall equation the result for the oil boom period, the elasticity of petroleum profit tax was unity. The other results followed the general results. The results for the period of the Structural Adjustment Programme (SAP) were not significantly different from those of the 'oil boom' and the entire period. The study concludes that administrative lags may have affected the remittance of tax revenues to government which may be responsible for the low productivity observed. We recommend that government should broaden the tax base and improve on administration of tax collection.
\end{abstract}

Keywords: Fiscal deficit, Productivity, Tax buoyancy, Tax elasticity, Tax revenue

\section{Introduction}

A careful study of the budget structure of Nigeria since her independence indicates that fiscal deficit is a recurring feature of the public sector financing. This is not surprising in view of the growing desire on part of the governments to provide for the demand for economic and social overheads as well as to enhance the living conditions of the citizenry. There is the view that fiscal deficits could be a veritable tool for enhancing accelerated growth and development in a developing economy (Thornton, 1990). This however would depend on the mode of financing the deficit and the sustainability of the fiscal deficit profile. Several options are open for financing fiscal deficits in a developing economy like Nigeria. These include: issuing new currency, drawing down the country's foreign assets and internal and external borrowing. Each of these financing options has its own 'good' and 'bad' effects. Proponents of fiscal deficits argue that it could in fact place more resources at the disposal of government for accelerated investment, thereby facilitating a faster growth. Critiques of fiscal deficits express the view that it may plunge the country into unprecedented borrowing thereby precipitating a debt burden and macroeconomic instability on the economy. Anyanwu (1997) opined that the size of public sector fiscal deficit is the most reliable indicator of overall macroeconomic stability or macroeconomic balance. $\mathrm{He}$ argued further that a high and persistent deficit is an indication of at least one type of macroeconomic imbalance such as inflation, foreign debt burden and balance of payment disequilibrium.

It is also suggested (Wicken \& Uctum, 1990) that the sustainability of a fiscal deficit profile is essential if it must stimulate growth. Studies indicate that in Nigeria even when revenue exceeds budgetary estimates, extra-budgetary expenditures have been rising, resulting in ever bigger fiscal deficits. Ariyo (1993) expressed the view that given the current trend, Nigeria may not be able to sustain the level of her fiscal deficit in the long-run. Zee (1988) suggested three options for addressing the problems of non-sustainability of fiscal deficits. These are: "(a) the determination of the optimal tax rate for a given level of expenditure; (b) the determination of the optimal level of expenditure for a given tax rate and (c) the simultaneous determination of the optimal level of expenditure and the tax rate" (Zee, 1988). 
Tax policies, tax laws and tax administration in Nigeria have undergone several changes in an effort to remedy inconsistencies, enhance its administration and boost its productivity. The question that prompted this study is whether the tax system in Nigeria is sufficiently productive to yield sufficient revenue for government budget. The objective of this paper therefore is to assess the productivity of the Nigeria tax system as a source of government revenue. If the tax system is unproductive, fiscal deficit would be unsustainable and may lead to insolvency. The outcome of this study would benefit budget preparation and implementation in Nigeria as it would enable planners to strike a trade-off between an optimal tax rate and the optimal level of expenditures. The study would also benefit policies and tax laws as it will bring to the fore the major weaknesses of the Nigeria tax system. The paper is organised in sections. Following the introduction, section 2 presents the review of literature. Section 3 presents the materials and methods. Section 4 presents the results while section 5 concludes.

\section{Review of Related Literature}

Ariyo and Raheem (1990) drew attention to the fact that the revenue and expenditure profile in Nigeria are not synchronized since 1970s. This according to them has caused the recurrent fiscal deficit profiles to be unsustainable. Ariyo (1993) applying test by Blinder and Solow (1973), Buiter (1983) and Zee (1988) concluded that Nigeria is unable to sustain her fiscal deficit profile in the past two decades. The World Bank (1988) attributed this to the fact that the Nigeria government is short-sighted in its revenue and expenditure policies as well as being biased towards overspending without regards to sustainability issues.

Alade (2003) opined that fiscal deficits could stimulate aggregate demand and set a country on the path of recovery. He noted that fiscal deficits raise the level of money supply which in turn sets in motion private sector wealth and asset portfolio decisions with respect to financial and real assets. This will affect the rate of interest which may lead to crowding-out effect of the private sector in funds allocation. If the financial institutions have sufficient liquidity, fiscal deficits have the potential of stimulating the economy. Also, fiscal deficits may affect the reserve base of the financial institutions leading to the creation of additional credits. Either way, fiscal deficit may contribute to output growth.

Iyoha (2004) opined that given the structural and systematic problems commonly associated with less developed countries, budget deficit invariably appears in the course of governance. Such are usually financed either by borrowing from the Central Bank, borrowing from the non-banking public or borrowing from external sources.

Given the narrow revenue base of the Nigerian economy, fiscal deficits would continue to be a recurring phenomenon. Until the country is able to harmonise its revenue and expenditure profile, fiscal deficits will continue to remain with us.

Following the advent of crude petroleum oil in the early 1970s, the structure of the federally collected revenue recorded major shifts. Revenue from non-oil exports declined steadily in the mid - 1970s and 1980s while oil revenue became the anchor for public expenditure programmes. For example, the contribution of oil revenue to total revenue increased from $18.9 \%$ in 1970 to $82.2 \%$ in 1989. Aghevli and Sassanpour (1982), Olopoenia (1991) Ariyo (1997), attributed the decline in non-oil revenue to a possible 'wealth effect' arising from the huge oil revenue. They noted that the extent to which the government withdraws resources from the non-oil sector may depend on its perception of the oil wealth. They argued that if oil wealth is perceived to be permanent, there may be a desire by government to transfer some of the wealth to the private non-oil sector through a reduction in non-oil tax burden. This decision explains the low tax effort in Nigeria especially in the non-oil sector.

In an effort to make the Nigeria tax system more productive, the Nigerian government in 1991, embarked on a study of the tax system management and administration in Nigeria. The outcome of that exercise was the creation of a comprehensive tax system reform agenda which aims at a tax system that would generate higher levels of revenue, economic efficiency, equity, fairness and simplicity. Although the tax reform efforts have broadened the structure of the tax system not much has been achieved in terms of tax administration.

\subsection{Theoretical/Conceptual Framework}

The productivity of a tax system in yielding sufficient revenue to meet government expenditure simply relates to the concept of efficiency in tax administration and collection. Two approaches are often used to evaluate the productivity of a tax system (Asher, 1989; Osoro, 1991). These are (1) Tax buoyancy (2) Income elasticity of tax system or simply tax elasticity.

Haughton (1998) defined tax revenue or revenue buoyancy as the rate of change in tax revenue with respect to the tax base, using numbers for the revenue and base actually observed. That is, tax buoyancy (TB) is given as: 


$$
\mathrm{TB}=\frac{\% \Delta \text { Revenue }}{\% \Delta \text { Base }}
$$

The base is taken as gross domestic product (GDP), although other bases such as, volume of import or total consumption as bases for tariffs and sales taxes respectively could be used. Similarly, Rao (1979), Murithi and Moyi (2003) provided an alternative measure of tax buoyancy as:

$$
\mathrm{TR}=\mathrm{aX} \mathrm{e}_{\mathrm{r}}
$$

Where: $T R=$ Total tax revenue, $X=$ GDP at current prices, and $\mathrm{e}_{\mathrm{r}}=$ the error term.

The log-transformation of Equation (2) yields:

$$
\log \mathrm{TR}=\log \mathrm{a}+\mathrm{b}_{\log } \mathrm{X}+\mathrm{e}_{\mathrm{r}}
$$

Where, $b$ provides a measure of tax buoyancy. It is more useful to measure tax buoyancy over a fairly long period of time say $5-10$ years to make room for stability.

Haughton (1998) also defined tax elasticity as the rate of change in tax revenue with respect to the base year. That is,

$$
\text { Tax Efficiency }(\mathrm{TE})=\frac{\% \Delta \text { Revenue }}{\% \Delta \text { Base }}
$$

The difference between equations (1) and (4) is that tax efficiency measures exclude the effect of discretionary changes in tax policy on tax revenue. Some operational difficulties have been noted in the use of eq. 4 above. First, there is the problem of lack of adequate data on revenue receipts directly and strictly attributable to discretionary changes in tax policy. Secondly, there is the problem of the assumption that the discretionary changes are as progressive as the underlying tax structure. And thirdly, the approach is highly aggregative.

Omoruyi (1983) provided an alternative measure of tax efficiency as:

$$
\frac{\Delta T}{\Delta Y} \times \frac{Y}{T}
$$

and for any given tax, $\mathrm{K}$, by

$$
\frac{\Delta T_{k}}{\Delta Y_{x}} \times \frac{Y}{T_{k}}
$$

Where $T_{K}$, the tax revenue, includes discretionary changes in the tax base and rate schedule and Y refers to GDP at current prices. Equation (6) contains two components, i.e.

(a) The elasticity of the tax to the base year. (b) The elasticity of the base year to income.

The tax to base year could be represented by

$$
\frac{\Delta T_{k}}{\Delta B_{x}} \times \frac{B}{T_{k}}
$$

and base-to-income elasticity as

$$
\frac{\Delta B_{k}}{Y_{x}} \times \frac{Y}{B_{k}}
$$

The relationship is expressed in the following identity:

$$
\frac{\Delta T_{k}}{\Delta Y_{x}} \times \frac{Y}{T_{k}}=\left[\frac{\Delta T_{k}}{\Delta B_{k}} \times \frac{B_{k}}{T_{k}}\right]\left[\frac{\Delta B_{k}}{\Delta Y_{k}} \times \frac{Y_{k}}{B_{k}}\right]
$$

Equation 7 indicates that any tax system is the product of elasticity of tax-to-base and of base to-income.

\section{Materials and Methods}

\subsection{Data Sources}

In carrying out this study, data on the following variables were collected from the publications of the Central Bank of Nigeria (Various issues) and the Nigerian Bureaux of Statistics. Considering various theoretical and empirical literature many variables have been identified as affecting tax buoyancy and tax elasticity. However, the main variables to be used in this study are: 
GTR $=$ Total Tax Revenue, GDP $=$ Gross Domestic Product, NGDP $=$ Non-Oil Gross Domestic Product, NOR $=$ Non-oil Total Revenue, CEXD $=$ Custom and Excise Duties, PPT $=$ Petroleum Profit Tax, TOR $=$ Total Oil Revenue, CIT $=$ Company Income Tax and TEXD $=$ Total Export Duties.

The regression analysis of the productivity of the Nigeria tax system was carried out using the Eviews statistical software. The multiple regression technique was employed as numerous variables are involved. We tested the variables for 'unit roots' using the ADF analysis to ascertain the time series properties of the variables and found that the variables could be characterised as 1(1). We regress the log of the tax base on the log of their respective tax sources over 1970-2010 periods. In order to account for the effects of the developments in the macro economy on the productivity of the tax system during the period under study, the analysis was disaggregated into the following periods.

$>\quad 1970-2010$, for an overall trend analysis.

> $1971-1985$ - represents Oil boom period.

> 1986 - 2010 SAP and Post-SAP period.

\subsection{Model Specification}

Based on data availability, the following multiple regression equation is specified for analysis to determine the productivity of the Nigeria Tax system. The OLS method was used to analyze the various equations.

$$
\text { GTR }=\mathrm{f}(\text { GDP, NGDP, TOR, NOR, CEXD, PPT, CIT, TEXP) }
$$

The regression equation for our analysis for the period under consideration is as shown below:

$$
\text { GTR }=a_{0}+a_{1} \text { GDP }+a_{2} \text { NGDP }+a_{3} \text { TOR }+a_{4} \text { NOR }+a_{5} \text { CEXD }+a_{6} \text { PPT }+a_{7} \text { CIT }+a_{8} \text { TEXP }
$$

However, in order to assess the revenue elasticity for individual variables used in this study, we also specified ten models which were also estimated by OLS method. Based on that, the following equations were analyzed.

$$
\begin{gathered}
\log \mathrm{GTR}=\mathrm{a}_{0}+\mathrm{a}_{1} \log \text { GDP } \\
\log \mathrm{NOR}=\mathrm{b}_{0}+\mathrm{b}_{1} \log \mathrm{NGDP} \\
\log \mathrm{CEXD}=\mathrm{c}_{0}+\mathrm{c}_{1} \log \text { GDP } \\
\log \mathrm{CEXD}=\mathrm{c}_{0}+\mathrm{c}_{1} \log \mathrm{NGDP} \\
\log \mathrm{PPT}=\mathrm{g}_{0}+\mathrm{g}_{1} \log \mathrm{TOR} \\
\log \mathrm{PPT}=\mathrm{d}_{0}+\mathrm{d}_{1} \log \text { GDP } \\
\log \mathrm{TOR}=\mathrm{g}_{0}+\mathrm{g}_{1} \log \text { GDP } \\
\log \mathrm{CIT}=\mathrm{i}_{0}+\mathrm{i}_{1} \log \text { GDP } \\
\log \mathrm{CIT}=\mathrm{i}_{0}+\mathrm{i}_{1} \log \mathrm{NGDP} \\
\log \mathrm{TEXP}=\mathrm{g}_{0}+\mathrm{g}_{1} \log \text { GDP }
\end{gathered}
$$

\section{Analysis of Results}

The regression results for equation 8 are reported in Table 1 . As noted earlier the data is disaggregate into three periods, i.e. $8 \mathrm{~A}, 8 \mathrm{~B}$ and $8 \mathrm{C}$ as indicated on the table. The variables were in logs.

From the regression models above, it is revealed that for the entire period i.e. model 8A, GDP, TOR, CIT, PPT, NGDP and TEXP have positive impact on government total revenue (GTR) while NOR and CEXD have negative influence on GTR. The regression also revealed that GDP and CIT have the most insignificant influence of 0.050 and 0.024 on GTR which may be due to low level of economic activities in the country. From the result also, it is observed that, a percentage change in TOR, PPT, NGDP and TEXP will increase GTR by $0.140,0.330$, 0.421 and 0.285 respectively while a percentage change in NOR and CEXD will decrease GTR by 0.124 and 0.141 . The t-values show that four of the estimated parameters (TOR, PPT, NGDP and TEXP) are statistically significant, while the other four (GDP, NOR, CIT and CEXD) are not significant. The F-statistic value of 59.87820 reveals that the estimated parameters are simultaneously significant. The coefficient of determination $\left(R^{2}\right)$ for the entire period shows that the data fit the model well because about $94 \%$ of the total variation in GTR is explained by the variation in all the variables used for the analysis. The DW statistic of 2.035461 shows that there is no positive autocorrelation. The dependent variable (GTR) and the explanatory variables are highly correlated and the overall regression is significant except for the NOR and CIT. 
The oil boom period in model $8 \mathrm{~B}$ also revealed a positive linear relationship between the variables and GTR except PPT which ironically exhibit a negative impact, contrary to the a priori expectation that a percentage change in PPT should lead to a positive change in GTR. The t-statistic revealed that only TOR and TEXP are statistically significant while all other variables are not. However, an $\mathrm{R}^{2}$ value shows that about $99 \%$ of the variation in GTR is explained by the variables used for the regression. On the other hand, the DW statistic of 2.096311 shows that there is no positive autocorrelation and the F-statistic of 54.71380 indicates that the parameters are simultaneously significant.

The SAP period i.e. model $8 \mathrm{C}$ presented above also did not reveal anything different, as only CEXD have a negative (-0.042) and insignificant impact on GTR while all other variables have positive impact on GTR. The $\mathrm{R}^{2}$ value shows that about $96 \%$ of the variation in GTR is explained by the variables used for the regression. The F-statistic of 39.77586 indicates that the parameters are simultaneously significant.

\subsection{Productivity of Nigeria Tax System (1970-2010)}

Table 2 shows the productivity indexes for the overall and individual revenue sources for the period 1970-2010.

Table 2 shows productivity indexes for the whole and the individual revenue sources for the period 1970-2010. The results indicate that out of the ten equations, 7 equations are statistically significant. But the elasticity indexes for all the tax sources are less than unity, as NOR do (eq. 2) have elasticity coefficient of 0.927 in relation to NGDP while TOR (eq. 7) has elasticity coefficient of 0.595 in relation to GDP. However, since all equations show positive elasticity coefficient, it implies that all revenue sources could contribute positively to government total revenue if well managed.

The lagged values of the explanatory variables (column 4 ) also showed that $70 \%$ of the ten equations had lower elasticity indexes of the tax sources relative to their respective tax bases, while the other three equations had elasticity indexes relatively higher than what was obtained in their current values (column 3). The finding from the lag values also indicates that $70 \%$ of the ten equations are statistically significant. Thus, from the findings, it could be argued that there is need to capture the effect of policy lags on tax yield. This was confirmed by Ariyo (1997) when he opined that apart from administrative lags, the enabling regulations allow for grace periods between the due date of a tax liability and the actual time to remit.

The reports from the oil boom period as seen from the table 3 above indicate some slight variation from what obtained during the entire period. Only three of the ten equations are statistically significant both for current and lag values. The coefficients of determination $\left(\mathrm{R}^{2}\right)$ do not show that, NOR, CEXD and PPT could explain over $80 \%$ of the pattern of the behaviour of each dependent variable. This is not unexpected as the neglect of the non-oil revenue (NOR) did source have significant impact on GTR. This also significantly affects CEXD and PPT respectively. The lagged values of the explanatory variables during the oil period also revealed only one of the equations $(10 \%)$ had elasticity indexes greater than 1 , while the other 9 of the equations had elasticity indexes relatively below unity with equations 2 and 4 having elasticity indexes of 0.861 and 0.725 respectively. Others have elasticity that is less than 0.5 .

The SAP period result in table 4 is also very interesting as it shows that all the variables have positive linear relationship with GTR. The result revealed that the coefficients in equations i, ii, iv, v, vii, ix and $\mathrm{x}$ are statistically significant while the coefficients in equations iii, vi and vii are not statistically significant for both current and lagged values. This further suggests that during the SAP period the administration and collection of non-oil revenue sources had some positive effect.

The elasticity indexes for all the tax sources showed positive elasticity coefficient. This finding is in line with Ariyo (1997) who established a significant relationship between GTR and the various tax sources and a link between the variables and the magnitude of the revenue involved.

\subsection{Index of Tax Buoyancy; 1970-2010}

To provide further evidence on the productivity of the Nigeria tax system, the index of tax buoyancy of the tax system was computed from equations $\mathrm{i}-\mathrm{x}$. In the computation, the data were divided into three groups and the results are recorded in Table 5. Group A shows the overall tax buoyancy, Group B is for the Oil Boom period while Group C recorded the SAP period.

For the entire period covered by this study, there was a buoyancy of 1.230 for GDP relative to GTR and 1.155 CEXD relative to NGDP. In fact, contrary to our expectations, the non-oil component however performed slightly lower with a buoyancy of $1.000,1.002$ and 1.004 respectively for the three periods. The result further revealed that the Nigeria tax structure is buoyant for about five of the tax sources while it is not buoyant for other five tax sources for the period under consideration. A tax structure is said to be buoyant if the buoyancy index is 
greater than unity, implying that as national income or the proxy base changes, tax revenue changes by a larger proportion as a result of built-in elasticity and discretionary changes (Okpara, 2010).

There was no significant change in the buoyancy for CEXD both in relation to GDP and NGDP respectively as they exhibited a buoyancy of approximately 1 . Generally, the results show the effect of administrative lags and lapses in the implementation of tax-related policies. This could be the lag between tax collection and remittance to government.

Column B of Table 5 (Oil Boom Period) shows that a buoyancy of 1.401 and 1.338 for GDP and TOR, were recorded. Although, the coefficient of buoyancy for PPT in relation to TOR remains high and this could be attributed to improvement in the prices of oil after 1985 and the deregulation of the oil sector. However, there was a downward trend when compared to Ariyo (1997) report, which establish a buoyancy coefficient of 2.60 and 1.88 for the same components. This downward trend may not be surprising phenomenon as the crises in the Niger Delta may have significantly affected oil production and revenues. The buoyancy of 0.644 for TOR during the oil boom was not encouraging compared with the general model which has a buoyancy of 0.893 and other study which establish a buoyancy of 1.21. This downward trend in the buoyancy for TOR however is a case that required further investigation.

\section{Conclusion}

This study was conducted to determine the productivity of the Nigeria's tax system during the $1970-2010$. Ten models were formulated for the study and the ordinary least square method was used to analyse the data. As a preliminary check, the ADF unit root test was used to determine the presence of unit roots. The variables were characterized as 1(0). The regression in logs was done using the data at levels.

To assess the productivity of the Nigeria tax system, two measures - index of tax efficiency and index of tax buoyancy developed by Houghton (1998) were adopted. In carrying out the analysis, the data set was disaggregated into sub-periods to enable us trace the effects of changes in the macroeconomic environment. The analysis was done at three levels of aggregation i.e. using the entire data set (Period A) at one level (1970-2010), the oil boom period (B) at another level (1970-1984) and the SAP and Post SAP period (C) at another (1986-2010).

The results of the analysis indicate that overall i.e. (Period A) 7 out of the 10 equations recorded elasticity index of less than 0.5 while the remaining 3 had elasticity of between 0.5 and 0.9 . The analysis for the oil boom period shows that the PPT has elasticity of 1.01 which indicates that the petroleum profit tax (PPT) is productive during the oil boom period. During this period, only 4 out of the 10 equations came out with elasticity of between 0.5 0.9 while the remaining 6 equations had elasticity of below 0.5 . This suggests that even during the oil boom period, the tax system was not productive. The analysis for the period of SAP was not significantly different from the preceding two analyses. It therefore follows that the Nigeria tax system is less productive irrespective of the level of data aggregation.

All over the world a productive tax system provides sufficient revenue for government spending. From our analysis this is not the case for Nigeria. The options open to government for closing the gap between revenue from the tax system and expenditure is to embark on fiscal deficit financing. This study has established that the persistent fiscal deficit financing in Nigeria is due to the unproductive tax system.

The study therefore recommends as follows:

First, the government has to broaden the tax base by providing the enabling environment for private enterprise to thrive. Secondly, the government should improve on tax administration so as to narrow the gap between tax collection and remittance to government coffers. Thirdly, government should also ensure that leakages in the administration of tax collection and tax revenue remittance are effectively checked. Fourth, government should deregulate economic activities substantially so as to enable the private sector to thrive. This will reduce the level of government expenditure such that revenue and expenditure are synchronised. This would control and significantly reduce public expenditure which is evidenced by the large number of the white elephant projects that dots the country. When this is done, huge sum of money would be saved to reduce fiscal deficit in the country. 


\section{References}

Aghevli, B. B., \& Sassanpour, C. (1982). Prices, output and the trade balance in Iran. World Development, 10, 791-800.

Alade, S. (2003). Fiscal adjustment in Nigeria: Issues in capital expenditure. The Bullion, 27 (2), 8-16.

Anyanwu, J. C. (1997). Nigerian Public Finance. Onitsha, Nigeria: Joanee Educational Publishers Limited.

Ariyo, A. (1993). An assessment of the sustainability of Nigeria's fiscal deficit: 1970-1990. Journal of African Economie, 2 (2), 263-282.

Ariyo, A. (1997). Productivity of the Nigerian Tax System: 1970-1990. Nairobi, Kenya: African Economic Research Consortium.

Ariyo, A., \& Raheem, M. I. (1990). Deficit financing and economic development: Empirical perspectives from Nigeria. Project Report Presented to the African Economic Research Consortium. Abidjan, December.

Ariyo, A., \& Raheem, M. I. (1991). Effect of fiscal deficit on some macroeconomic aggregates in Nigeria. Final Report Presented at the Workshop of the African Economic Research Consortium, Nairobi, Kenya, 7-11 December.

Asher, M. G. (1989). Fiscal Systems and Practices in ASEAN: Trends, Impact and Evaluation. Singapore: Institute of South-East Asian Studies. At a workshop on Quality of African Data organized by the African Economic Research Consortium. Nairobi, Kenya, 11-12 February.

Blinder, A. S., \& R. M. Solow. (1973). Does fiscal policy matter? Journal of Public Economics, 2, 319-337.

Buiter, W. (1983). The Theory of Optimum Deficits and Debt. NBER Working Paper No. 1232. Draft Document on the National Tax Policy, updated as at 7 June 2008. (Presentation by the Presidential Committee on National Tax Policy).

Haughton, J. (1998). Estimating Tax Buoyancy Elasticity and Stability. Eager/PSGE-Excise Project, Methodological Note 1.

Iyoha, M. A. (2004). Macroeconomics, theory and policy. Benin-City, Nigeria: Mindex Publishing.

Murithi, K. M., \& Moyi, E. D. (2003). Tax Reforms and Revenue Mobilization in Kenya, EERC Research Paper, 131, African Economic Research Consortium, Nairobi.

Osoro, N. M. (1993). Revenue Productivity Implications of Tax Reform in Tanzania, African Economic Research Consortium, Nairobi September 1993.

Okpara, G. C. (2010). Productivity and the effect of taxation on economic growth in Nigeria. International Journal of Research in Commerce and Management, 1 (6).

Olopoenia, R. A. (1991). Fiscal response to oil wealth and balance of payments performance in Nigeria, 1970-1989. Final report presented at the African Economic. Research Consortium's Workshop. Nairobi. Kenya. 7-11 December.

Omoruyi, S. E. (1983). Growth and Flexibility of Federal Government Tax Revenue: 1960-1979. Economic and Financial Review, 21 (1), 11-19.

Osoro, N. E. (1985). The Buoyancy and Elasticity of the Tanzania Tax Structure: 1969170-1980/81, Ph.D. Thesis presented to University of Illinois, Urbana-Champaign.

Rao, V. G. (1979). The Responsiveness of the Indian Tax System, 1969/70-1973/74. Bangalore: Allied.

Thornton, D. L. (1990). Do government deficits matter? A review. The Federal Reserve Bank of St. Louis, 72 (5), 25-39.

Wickens, M. R., \& Uctum, M. (1990). National insolvency: A test of the us inter- temporal budget constraint. Centre for Economic Policy Research. Discussion Paper Series, No. 437, August.

Zee, H. H. (1988). The sustainability and optimality of government debt. IMF Staff Papers, 35, 658-685. 
Table 1. Results of the OLS regression (DEPENDENT VARIABLE $=$ GTR)

\begin{tabular}{|c|c|c|c|}
\hline & $\begin{array}{c}\text { Model 8(a) } \\
\text { Overall } \\
(1970-2010)\end{array}$ & $\begin{array}{c}\text { Model 8(B) } \\
\text { Oil-Boom Period } \\
(1971-1985)\end{array}$ & $\begin{array}{c}\text { Model }(\mathrm{C}) \\
\text { SAP Period } \\
(1986-2010)\end{array}$ \\
\hline Variable & Coefficient & Coefficient & Coefficient \\
\hline Constant & $\begin{array}{l}-0.00337 \\
(-0.1358)\end{array}$ & $\begin{array}{c}-0.0378 \\
(-1.2210)\end{array}$ & $\begin{array}{l}+0.0857 \\
(-1.3100)\end{array}$ \\
\hline LGDP & $\begin{array}{c}0.51 \\
(0.9946)\end{array}$ & $\begin{array}{c}0.045 \\
(1.1528)\end{array}$ & $\begin{array}{c}0.105 \\
(0.8267)\end{array}$ \\
\hline LTOR & $\begin{array}{c}0.140 \\
(3.9812)\end{array}$ & $\begin{array}{c}0.722 \\
(2.3940)\end{array}$ & $\begin{array}{c}0.110 \\
(2.6412)\end{array}$ \\
\hline LNOR & $\begin{array}{c}-0.124 \\
(0.8100)\end{array}$ & $\begin{array}{c}0.161 \\
(0.69921)\end{array}$ & $\begin{array}{c}+0.158 \\
(-0.3037)\end{array}$ \\
\hline LCEXD & $\begin{array}{c}-0.141 \\
(1.7675)\end{array}$ & $\begin{array}{c}0.175 \\
(1.1841)\end{array}$ & $\begin{array}{c}-0.042 \\
(-0.3353)\end{array}$ \\
\hline LPPT & $\begin{array}{c}0.330 \\
(7.1438)\end{array}$ & $\begin{array}{c}-0.355 \\
(-1.3537)\end{array}$ & $\begin{array}{c}0.394 \\
(6.8650)\end{array}$ \\
\hline LCIT & $\begin{array}{c}0.024 \\
(0.3098)\end{array}$ & $\begin{array}{c}0.0234 \\
(0.3818)\end{array}$ & $\begin{array}{c}0.167 \\
(0.8944)\end{array}$ \\
\hline LNGDP & $\begin{array}{c}0.421 \\
(2.6773)\end{array}$ & $\begin{array}{c}0.0700 \\
(0.3597)\end{array}$ & $\begin{array}{c}0.492 \\
(0.9108)\end{array}$ \\
\hline LTEXP & $\begin{array}{c}0.285 \\
(5.0190)\end{array}$ & $\begin{array}{c}0.440 \\
(3.6178)\end{array}$ & $\begin{array}{c}0.241 \\
(2.65321)\end{array}$ \\
\hline $\mathrm{R}^{2}$ & 0.9392 & 0.9887 & 0.9578 \\
\hline $\mathrm{F}$ & 59.8782 & 54.7138 & 39.7758 \\
\hline D.W & 2.03 & 2.09 & 1.69 \\
\hline
\end{tabular}

$\mathrm{t}$-values are in parenthesis.

Source: Authors' calculations

Table 2. Productivity Indexes of the Nigerian Tax System, 1970 - 2010

\begin{tabular}{|c|c|c|c|c|c|c|c|}
\hline Equations & Constant & $\begin{array}{l}\text { Elasticity } \\
\text { Coefficient }\end{array}$ & $\begin{array}{c}\text { Elasticity } \\
\text { Coefficient (Lag } \\
\text { Values) }\end{array}$ & F-stat & $\mathrm{R}^{2}$ & DW & SER \\
\hline 1 & $\begin{array}{c}0.159 \\
(2.800)\end{array}$ & $\begin{array}{c}0.428 \\
(2.855)\end{array}$ & $\begin{array}{c}0.442 \\
(2.972)\end{array}$ & 81.489 & 0.87 & 2.377406 & 0.150 \\
\hline 2 & $\begin{array}{c}0.015 \\
(0.766)\end{array}$ & $\begin{array}{c}0.927 \\
(17.215)\end{array}$ & $\begin{array}{c}0.927 \\
(16.976)\end{array}$ & 256.364 & 0.88 & 3.101980 & 0.054 \\
\hline 3 & $\begin{array}{c}0.156 \\
(3.375)\end{array}$ & $\begin{array}{c}0.098 \\
(0.806)\end{array}$ & $\begin{array}{c}0.094 \\
(0.763)\end{array}$ & 36.499 & 0.72 & 2.366269 & 0.122 \\
\hline 4 & $\begin{array}{c}0.063 \\
(1.637)\end{array}$ & $\begin{array}{c}0.527 \\
(5.041)\end{array}$ & $\begin{array}{c}0.526 \\
(4.971)\end{array}$ & 225.409 & 0.80 & 2.282466 & 0.105 \\
\hline 5 & $\begin{array}{c}0.119 \\
(1.776)\end{array}$ & $\begin{array}{c}0.494 \\
(4.742)\end{array}$ & $\begin{array}{c}0.493 \\
(4.657)\end{array}$ & 224.847 & 0.77 & 2.637976 & 0.104 \\
\hline 6 & $\begin{array}{c}0.197 \\
(2.299)\end{array}$ & $\begin{array}{c}0.291 \\
(1.287)\end{array}$ & $\begin{array}{c}0.299 \\
(1.304)\end{array}$ & 165.611 & 0.74 & 2.106599 & 0.226 \\
\hline 7 & $\begin{array}{c}0.156 \\
(1.533)\end{array}$ & $\begin{array}{c}0.595 \\
(2.219)\end{array}$ & $\begin{array}{c}0.607 \\
(2.240)\end{array}$ & 149.209 & 0.97 & 2.409109 & 0.268 \\
\hline 8 & $\begin{array}{c}0.216 \\
(5.660)\end{array}$ & $\begin{array}{c}0.136 \\
(1.347)\end{array}$ & $\begin{array}{c}0.133 \\
(1.304)\end{array}$ & 94.068 & 0.82 & 2.532980 & 0.101 \\
\hline 9 & $\begin{array}{c}0.248 \\
(5.842)\end{array}$ & $\begin{array}{l}-0.060 \\
(2.077)\end{array}$ & $\begin{array}{c}0.221 \\
(2.040)\end{array}$ & 127.071 & 0.60 & 2.459585 & 0.114 \\
\hline 10 & $\begin{array}{c}0.163 \\
(2.368)\end{array}$ & $\begin{array}{c}0.414 \\
(2.267)\end{array}$ & $\begin{array}{c}0.417 \\
(2.253)\end{array}$ & 51.413 & 0.71 & 2.393816 & 0.182 \\
\hline
\end{tabular}

$\mathrm{t}$-values are in parenthesis

Source: Authors's calculations 
Table 3. The oil boom and the tax yield (1970 - 2010)

\begin{tabular}{|c|c|c|c|c|c|c|c|}
\hline Equations & Constant & $\begin{array}{l}\text { Elasticity } \\
\text { Coefficient }\end{array}$ & $\begin{array}{c}\text { Elasticity } \\
\text { Coefficient (Lag } \\
\text { Values) }\end{array}$ & F-stat & $\mathrm{R}^{2}$ & DW & SER \\
\hline 1 & $\begin{array}{c}0.177 \\
(1.996)\end{array}$ & $\begin{array}{c}0.171 \\
(0.923)\end{array}$ & $\begin{array}{c}0.164 \\
(0.850)\end{array}$ & 18.52 & 0.67 & 1.595780 & 0.185 \\
\hline 2 & $\begin{array}{c}0.051 \\
(1.277)\end{array}$ & $\begin{array}{c}0.788 \\
(6.219)\end{array}$ & $\begin{array}{c}0.861 \\
(9.940)\end{array}$ & 138.67 & 0.76 & 2.039666 & 0.127 \\
\hline 3 & $\begin{array}{c}0.125 \\
(1.559)\end{array}$ & $\begin{array}{c}-0.037 \\
(-0.221)\end{array}$ & $\begin{array}{c}-0.057 \\
(-0.346)\end{array}$ & 104.78 & 0.73 & 2.090972 & 1.667 \\
\hline 4 & $\begin{array}{l}0.018) \\
(0.399)\end{array}$ & $\begin{array}{c}0.758 \\
(5.258)\end{array}$ & $\begin{array}{c}0.725 \\
(4.946)\end{array}$ & 227.64 & 0.76 & 2.577942 & 0.144 \\
\hline 5 & $\begin{array}{l}-0.020 \\
(-0.397)\end{array}$ & $\begin{array}{c}1.063 \\
(12.009)\end{array}$ & $\begin{array}{c}1.070 \\
(11.850)\end{array}$ & 184.26 & 0.92 & 2.386255 & 0.089 \\
\hline 6 & $\begin{array}{c}0.236 \\
(1.543\end{array}$ & $\begin{array}{c}0.255 \\
(0.801)\end{array}$ & $\begin{array}{c}0.255 \\
(0.764)\end{array}$ & 16.24 & 0.80 & 1.609720 & 0.318 \\
\hline 7 & $\begin{array}{c}0.231 \\
(1.700)\end{array}$ & $\begin{array}{c}0.292 \\
(1.031)\end{array}$ & $\begin{array}{c}0.286 \\
(0.964)\end{array}$ & 106.33 & 0.81 & 1.852634 & 0.282 \\
\hline 8 & $\begin{array}{c}0.182 \\
(1.965\end{array}$ & $\begin{array}{l}-1.640 \\
(2.220)\end{array}$ & $\begin{array}{c}0.141 \\
(0.706)\end{array}$ & 19.40 & 0.75 & 2.37441 & 0.192 \\
\hline 9 & $\begin{array}{c}0.167 \\
(1.772)\end{array}$ & $\begin{array}{c}0.205 \\
(0.913)\end{array}$ & $\begin{array}{c}0.314 \\
(1.002)\end{array}$ & 51.10 & 0.86 & 2.659320 & 0.323 \\
\hline 10 & $\begin{array}{l}0.160 \\
1.523\end{array}$ & $\begin{array}{c}0.036 \\
(0.165)\end{array}$ & $\begin{array}{c}0.038 \\
(0.165)\end{array}$ & 146.07 & 0.82 & 1.919311 & 0.219 \\
\hline
\end{tabular}

$\mathrm{t}$-values are in parenthesis

Source: Authors' calculations

Table 4. SAP and Tax Yield 1970 - 2010

\begin{tabular}{|c|c|c|c|c|c|c|c|}
\hline Equations & Constant & $\begin{array}{c}\text { Elasticity } \\
\text { Coefficient }\end{array}$ & $\begin{array}{c}\text { Elasticity } \\
\text { Coefficient } \\
\text { (Lag Values) }\end{array}$ & F-stat & $\mathrm{R}^{2}$ & DW & SER \\
\hline $\mathrm{i}$ & $\begin{array}{c}0.167 \\
(1.458)\end{array}$ & $\begin{array}{c}0.885 \\
(3.845)\end{array}$ & $\begin{array}{c}0.930 \\
(4.163)\end{array}$ & 147.82 & 0.60 & 2.332777 & 0.230 \\
\hline ii & $\begin{array}{c}-0.004 \\
(-0.306)\end{array}$ & $\begin{array}{c}1.014 \\
(15.671)\end{array}$ & $\begin{array}{c}1.014 \\
(14.766)\end{array}$ & 172.45 & 0.98 & 1.929312 & 0.028 \\
\hline iii & $\begin{array}{c}0.155 \\
(2.714)\end{array}$ & $\begin{array}{c}0.340 \\
(1.890)\end{array}$ & $\begin{array}{c}0.328 \\
(1.777)\end{array}$ & 35.602 & 0.64 & 1.897941 & 0.180 \\
\hline iv & $\begin{array}{c}0.120 \\
(2.142)\end{array}$ & $\begin{array}{c}0.381 \\
(2.759)\end{array}$ & $\begin{array}{c}0.375 \\
(2.669)\end{array}$ & 76.106 & 0.73 & 1.561436 & 0.138 \\
\hline $\mathrm{v}$ & $\begin{array}{c}0.164 \\
(1.736)\end{array}$ & $\begin{array}{c}0.317 \\
(2.408)\end{array}$ & $\begin{array}{c}0.315 \\
(2.329)\end{array}$ & 58.00 & 0.61 & 2.483943 & 0.132 \\
\hline vi & $\begin{array}{c}0.182 \\
(1.566)\end{array}$ & $\begin{array}{c}0.378 \\
(1.031)\end{array}$ & $\begin{array}{c}0.402 \\
(1.070)\end{array}$ & 106.24 & 0.74 & 2.168639 & 0.367 \\
\hline vii & $\begin{array}{c}0.066 \\
(0.4310\end{array}$ & $\begin{array}{c}1.143 \\
(2.368)\end{array}$ & $\begin{array}{c}1.185 \\
(2.408)\end{array}$ & 56.08 & 0.80 & 2.406367 & 0.483 \\
\hline viii & $\begin{array}{c}0.244 \\
(7.544)\end{array}$ & $\begin{array}{c}0.145 \\
(1.429)\end{array}$ & $\begin{array}{c}0.136 \\
(1.311)\end{array}$ & 20.43 & 0.51 & 2.326573 & 0.102 \\
\hline ix & $\begin{array}{c}0.226 \\
(7.000)\end{array}$ & $\begin{array}{c}0.172 \\
(2.171)\end{array}$ & $\begin{array}{c}0.168 \\
(2.091)\end{array}$ & 47.12 & 0.67 & 2.051265 & 0.080 \\
\hline $\mathrm{x}$ & $\begin{array}{c}0.104 \\
(1.249)\end{array}$ & $\begin{array}{c}1.076 \\
(4.103)\end{array}$ & $\begin{array}{c}1.090 \\
(4.050)\end{array}$ & 16.834 & 0.53 & 2.070281 & 0.262 \\
\hline
\end{tabular}

$\mathrm{t}$-values are in parenthesis

Source: Authors' calculations 
Table 5. Index of Tax Buoyancy 1970 - 2010

\begin{tabular}{cccc}
\hline Equation & Overall Tax Buoyancy $(\mathrm{A})$ & Oil-Boom Period $(\mathrm{B})$ & SAP/Post SAP Period $(\mathrm{C})$ \\
\hline 1 & 1.230 & 1.401 & 1.133 \\
2 & 1.000 & 1.002 & 1.004 \\
3 & 1.007 & 1.338 & 0.871 \\
4 & 1.155 & 1.122 & 1.202 \\
5 & 1.127 & 1.090 & 1.045 \\
6 & 0.878 & 0.702 & 0.722 \\
7 & 0.893 & 0.644 & 0.691 \\
8 & 0.815 & 0.704 & 0.671 \\
9 & 0.934 & 0.828 & 0.926 \\
10 & 0.779 & 0.887 & 0.670 \\
\hline
\end{tabular}

